\title{
Optical and scintillation properties of Csl:In crystals
}

\author{
S.Gridin, N.Shiran, M.Moszynski ${ }^{*}$, A.Belsky ${ }^{* *}$, \\ A.Syntfeld-Kazuch", V.Tarasov, A.Gektin \\ Institute for Scintillation Materials, STC "Institute for Single \\ Crystals",National Academy of Sciences of Ukraine, \\ 60 Lenin Ave., 61001 Kharkiv, Ukraine \\ "National Centre for Nuclear Research, PL 05-400 Otwock-Swierk, Poland \\ "Institut Lumiere Matiere, Universite Claude Bernard Lyon 1, \\ 69622 Villeurbanne Cedex, France
}

Received March 12, 2013

\begin{abstract}
The work is dedicated to study of optical and scintillation properties of Csl:In crystals. Using the Bridgeman method a concentration row of CsI:In single crystals was grown with the dopant content from $10^{-4}$ to $10^{-1} \mathrm{~mol}$. \%. The segregation coefficient of In in Csl was estimated to be $\sim 0.15$. In Csl:In luminescence spectra one symmetric band is observed, peaking around $545 \mathrm{~nm}$, with FWHM of $0.46 \mathrm{eV}$. Under intracenter excitation $1.9 \mu \mathrm{s}$ exponential decay was observed. The light yield under gamma excitation of ${ }^{137} \mathrm{Cs}$ isotope $(662 \mathrm{keV})$, measured with a shaping time of $10 \mu \mathrm{s}$, was 27000 photons/MeV. The radioluminescence yield of CsI:In, measured by the current mode method, approached to that of CsI:TI. Probably, this difference is connected with the presence of a stronger afterglow in Csl:In crystals.
\end{abstract}

Работа посвящена исследованию оптических и сцинтилляционных свойств кристаллов Csl:In. Методом Бриджмена выращен концентрационный ряд монокристаллических образцов Csl:In с содержанием активатора от $10^{-4}$ до $10^{-1}$ мол. \%. Коэффициент сегрегации In в CsI составляет 0.15 . В спектре люминесценции наблюдается одна симметричная полоса c максимумом 545 нм, полушириной 0.46 эВ. При внутрицентровом возбуждении наблюдается экспоненциальное затухание с характерным временем 1.9 мкс. Световой выход при возбуждении гамма-квантами изотопа ${ }^{137} \mathrm{Cs}$ с энергией 662 кэВ при измерении с временными воротами 10 мкс составил 27000 фотонов/МэВ. Тем не менее, при измерении токовым методом выход радиолюминесценции Csl:In приближается к выходу Csl:TI. Вероятно, такое различие связано с наличием более сильного послесвечения в кристаллах Csl:In.

Оптичні та сцинтилящійні властивості кристалів Csl:In. С.Грідін, Н.Ширан, М.Мосжинський, А.Бельський, А.Синтфельд-Казух, В.Тарасов, О.Гектін.

Роботу присвячено дослідженню оптичних і сцинтиляційних властивостей кристалів Csl:In. Методом Бриджмена вирощено концентраційну серію монокристалічних зразків Csl:In 3 вмістом активатора від $10^{-4}$ до $10^{-1}$ мол. \%. Коефіцієнт сегрегації In в CsI становить 20.15 . У спектрі люмінесценції наявна одна симетрична полоса з максимумом 545 нм та півшириною 0.46 эВ. При активаторному збудженні спостерігається експоненційне загасання з характерним часом 1.9 мкс. Світловий вихід при збудженні гамма-квантами ізотопу ${ }^{137} \mathrm{Cs}$ з енергією 662 кеВ при вимірюванні з часом генерації імпульсу 10 мкс склав 27000 фотонів/МеВ. Тим не менше, при вимірюванні токовим методом вихід радіолюмінісценції Csl:In наближається до виходу Csl:TI. Вірогідно, така відмінність пов'язана з наявністю більш сильного післясвітіння у кристалах Csl:In. 


\section{Introduction}

Csl crystals are the basis for efficient scintillators. Undoped CsI scintillators have a short decay time and are successfully used in high energy physics $[1,2]$. Csl:TI, Csl:Na and $\mathrm{Csl}: \mathrm{CO}_{3}$ - are widely known as spectroscopic scintillators for various industrial and medical applications [3, 4]. Thus, there are certain general regularities allowing to obtain an efficient scintillation response in differently doped cesium iodide crystals. It is reasonable to assume that with some other dopants an efficient scintillation material based on Csl could be made. To check this assumption it seems appropriate to study scintillation characteristics of Csl:In crystals.

First of all it should be mentioned that $\mathrm{In}^{+}$ions are homologues of $\mathrm{Tl}^{+}$ions and have a similar $s^{2}$ electronic configuration in Csl lattice. Therefore we can expect the optical properties of Csl:In crystal and traditional Csl:TI scintillator to be similar. There are only several descriptions of Csl:In spectroscopic properties $[5,6]$. It is known that the luminescence band has a maximum around $545 \mathrm{~nm}$ which coincides well with spectral sensitivity of silicon photodiodes. At the same time, the scintillation properties are practically not studied. The only known thing is the temperature dependence of light output under $\alpha$ - and $\gamma$-excitation [7].

The aim of the present work is to study luminescent and scintillation properties of Csl:In crystals to determine the potential of their use as scintillation detectors.

\section{Experimental}

Pure and In doped CsI crystals (indium concentrations from $10^{-4}$ to $10^{-1}$ mass. \%) have been grown from pure dry salt Csl (5N) and $I n l(4 N)$ dope. Bridgman technique in evacuated sealed quartz ampoules was used for the single crystal growth. The polished plates of $2 \mathrm{~mm}$ thickness were used for absorption and luminescence measurements. Content of $\mathrm{In}^{+}$ions in the samples was determined by chemical and absorption methods. The segregation coefficient was found to be around 0.15. A photo of CsI:In crystal is presented in Fig. 1 .

The absorption spectra in UV-VIS range were measured at room temperature by means of SPECORD 40 spectrophotometer. Using IR spectroscopy methods, trace amounts of some oxyanion radicals, in particular $\mathrm{OH}^{-}$and $\mathrm{CO}_{3}{ }^{2-}$ were observed in the investigated crystals. Spectral and kinetic

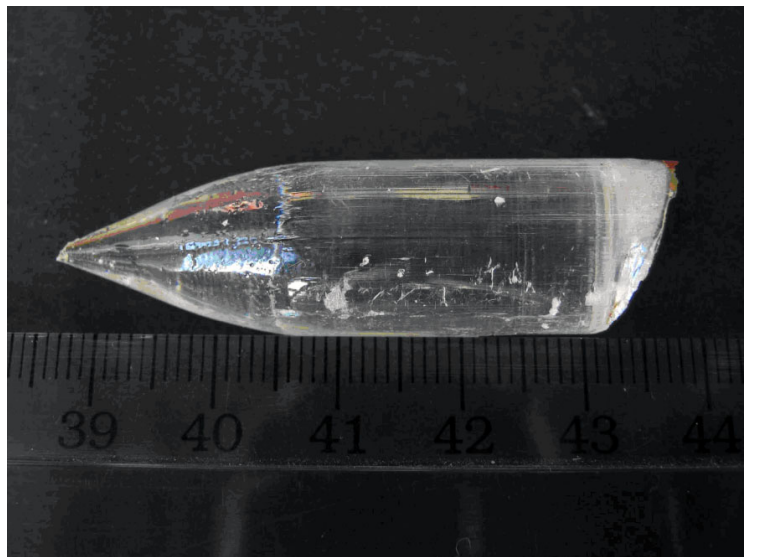

Fig. 1. Csl:In single crystal.

characteristics of photoemission were obtained using FLS 920 combined steady state fluorescence lifetime spectrometer. Xenon lamp Xe900, 450V was used as a source of $\mathrm{UV}$ excitation. X-ray luminescence was excited by a Cu-anode X-ray tube $(40 \mathrm{kV}$, $40 \mu \mathrm{A})$. Irradiation of the samples for radiation stability investigation was performed by an X-ray tube with W-anode, $9 \mathrm{~mA}, 160 \mathrm{kV}, 10 \mathrm{~Gy} / \mathrm{min}$.

Cylinders $\varnothing 14 \times 20 \mathrm{~mm}^{2}$ were used for scintillation parameters measurements. For the sake of comparison, standard Csl:TI crystalline samples of the industrial manufacture [8] were used. Relative light yield was measured using the current mode method with respect to a standard Csl:TI, and also by the position of the photo-peak of pulse height spectra under gamma-excitation of ${ }^{137} \mathrm{Cs}(662 \mathrm{keV})$. Absolute values of the light yield were obtained by the technique [9] using a calibrated XP2020Q PMT.

\section{Results and discussion}

\subsection{Absorption and luminescence properties}

Absorption spectra of Csl, Csl:TI and CsI:In crystals are presented in Fig. 2. In Csl:In and Csl:TI within the region of 240$310 \mathrm{~nm}$ absorption bands are observed, corresponding to intracenter transitions in the activator ions. $A$-bands of absorption with maxima of $310 \mathrm{~nm}$ and $299 \mathrm{~nm}$ (for Csl:In and Csl:TI, respectively) correspond to partially allowed ${ }^{1} S_{0} \rightarrow{ }^{3} P_{1}$ transitions. In weakly doped CsI:In crystals at $300 \mathrm{~K} B$ absorption bands $-290 \mathrm{~nm}\left({ }^{1} S_{0} \rightarrow{ }^{3} P_{2}\right.$ transitions) and $C-$ of 260-270 $\mathrm{nm}\left({ }^{1} S_{0} \rightarrow{ }^{1} P_{1}\right)$ [10] are also observed. In general, the spectra are similar but in the crystals contain- 


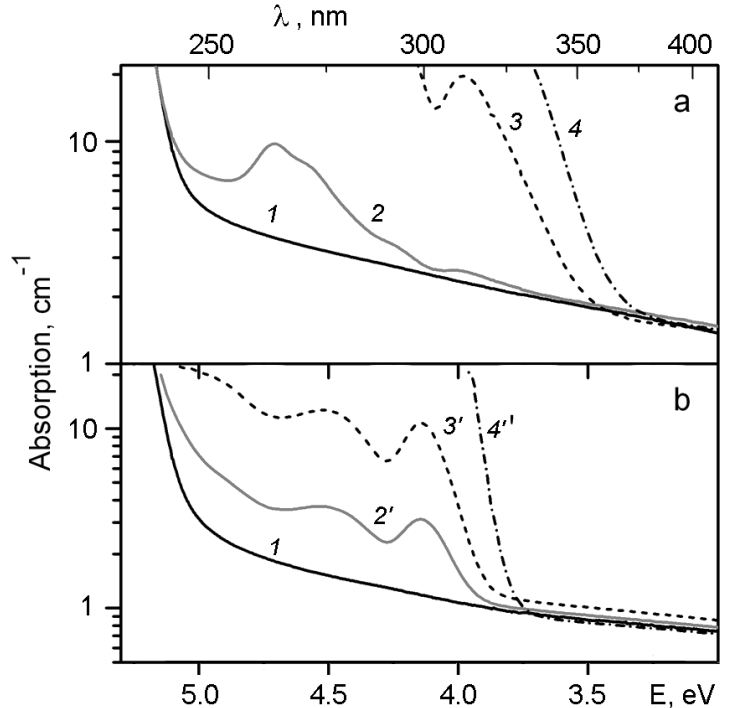

Fig. 2. Absorption spectra of pure Csl (curve 1); Csl:In (a): $2-10^{-4} \% \ln , 3-0.005 \%$ In, $4-0.045 \%$ In; and Csl:TI (b): $2^{\prime}-10^{-4} \%$ TI, $3^{\prime}-5 \cdot 10^{-4} \% \mathrm{TI}, 4^{\prime}-0.021 \% \mathrm{TI}$.

ing In the activator bands are slightly shifted to the low-energy region.

The band with the maximum of $545 \mathrm{~nm}$ can be observed in Csl:In luminescence spectrum at room temperature, under both intracenter and X-ray excitation (Fig. 3). Luminescence and excitation spectra do not overlap which confirms the absence of reabsorption. The luminescence spectrum under photo-excitation almost does not depend on indium content. Unlike Csl:TI crystal (maximum - $550 \mathrm{~nm}$, FWHM $0.71 \mathrm{eV}$ ), in Csl:In the luminescence band has a much smaller FWHM $(0.46 \mathrm{eV})$, the additional luminescence band around $400 \mathrm{~nm}$ is also absent.

Csl:In crystals show exponential decay of luminescence with the decay time constant of $1900 \mathrm{~ns}$ under intracenter excitation (Fig. 4). The decay constant does not depend on the indium concentration. At the same time, excitation at the edge of the fundamental absorption $(230 \mathrm{~nm})$ reveals a longer decay component.

Under X-ray excitation $545 \mathrm{~nm}$ band predominates in the luminescence spectra (like under photo-excitation). In addition, the band of intrinsic luminescence in the region of $300 \mathrm{~nm}$ is also observed (Fig. 5). With an increase of the activator content, UV emission intensity falls down, and at In concentrations higher than $10^{-2} \mathrm{~mol}$. \% it is completely suppressed.

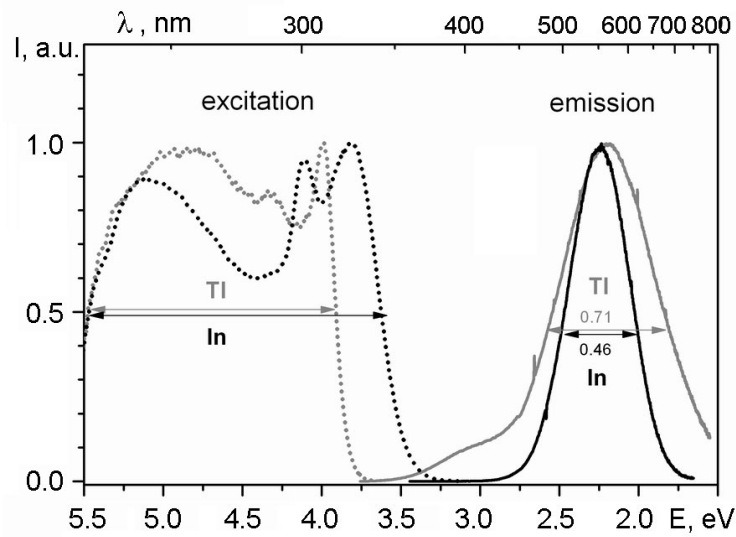

Fig. 3. Emission (solid) and excitation (dotted) spectra of CsI:In and CsI:TI.

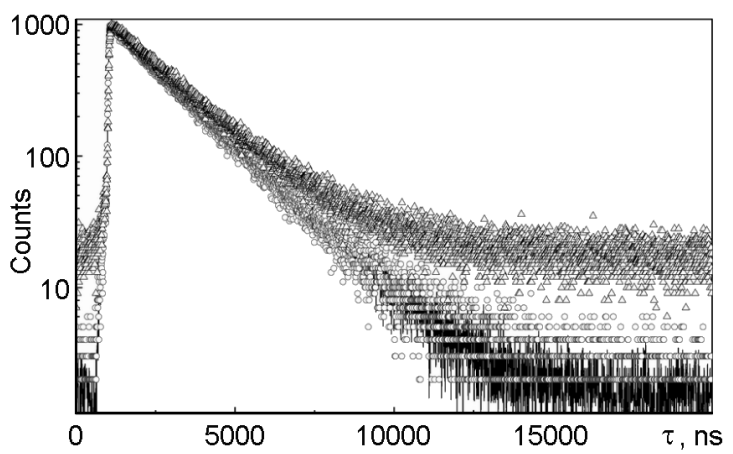

Fig. 4. Decay kinetics of $550 \mathrm{~nm}$ luminescence for Csl:In at different excitation wavelengths: $330 \mathrm{~nm}$ - solid, $250 \mathrm{~nm}$ - circles, $230 \mathrm{~nm}$ - triangles.

\subsection{Scintillation properties}

Pulse height spectra of Csl:In and Csl:TI crystals, measured with the shaping time of $12 \mu \mathrm{s}$ under ${ }^{137} \mathrm{Cs}$ source $(662 \mathrm{keV})$ are shown in Fig. 6. It can be seen that the light yield of the In-doped crystal is about $50 \%$ of Csl:Tl. Absolute light yield of Csl:In measured using the method [9] gives 27000 photons/MeV (with triangle shaping time $10 \mu \mathrm{s})$. Light output of CsI:In crystal, measured using the current mode method under ${ }^{90} \mathrm{Sr}-{ }^{90} \mathrm{Y} \beta$-excitation $(546 \mathrm{keV}$ ), attains Csl:TI yield. This means that almost a half of the emitted light has slow components, not registered within the used time gates. Actually, measurement of the afterglow after $150 \mathrm{~ms}$ has shown that the signal in Csl:In is 4-5 times higher than the equivalent signal level of Csl:TI crystals.

Under a pulsed X-ray excitation, Csl:In luminescence has in general an exponential 


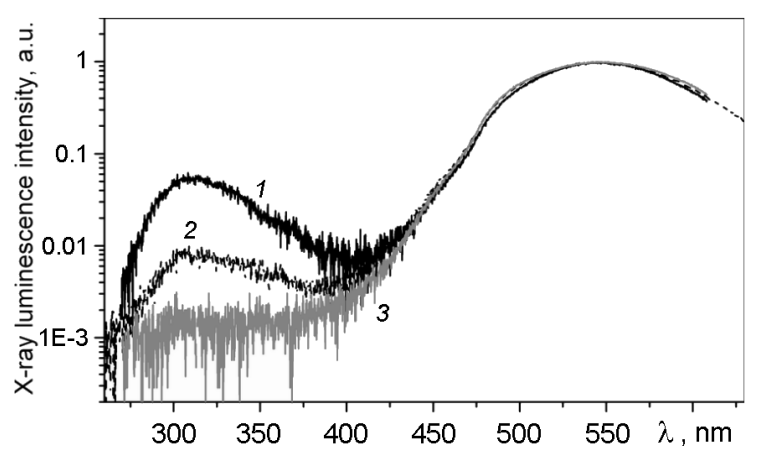

Fig. 5. X-ray luminescence of Csl:In crystals at $300 \mathrm{~K}$, depending on the dopant concentration: $1-0.002 \% \ln , 2-0.005 \% \ln , 3-$ $0.029 \%$ In.

decay component about $2.1 \mu \mathrm{s}$, which is close to the decay time obtained by us under intracenter activator excitation (1.9 $\mu \mathrm{s})$. Whereas a decay with the exponential part of about $1.0 \mu \mathrm{s}$ is usually observed for Csl:TI.

The inset of Fig. 6 demonstrates the concentration dependence of Csl:In light yield relative to a standard Csl:TI scintillator, measured by the current mode method circles, and by the position of the photopeak - squares. With the concentration increasing up to $\sim 0.02 \mathrm{~mol}$. \% In, the light yield of Csl:In crystal measured by both methods reaches a saturation.

\subsection{Radiation damage}

First of all it should be noted that the exposure of the samples to day light $(>360 \mathrm{~nm}, 12 \mathrm{~h})$ and to UV photons (254 nm, Hg-lamp, $\sim 1 \mathrm{~h}$ ) does not reveal any coloration of Csl:In crystals. At the same time, X-irradiation leads to the formation of coloring of the samples with the high indium content (0.05 and $0.1 \%)$. Absorption spectra of the colored Csl:In samples manifest a set of overlapping bands in the visible and near IR regions (Fig. 7). The most intensive bands, peaking around 518, $582-610,800-900 \mathrm{~nm}$, progressively decay during the crystals storage at room temperature. Similar band structure in the absorption spectrum of the irradiated crystals was also observed in Csl:TI crystals and was attributed to transitions in $\mathrm{Tl}^{+}$or $\mathrm{Tl}^{0}$, localized in the vicinity of some defects [11]. Bands in the region of $800 \mathrm{~nm}$ can be connected with $F$-type centers, distorted by the presence of the dopant ions [12].

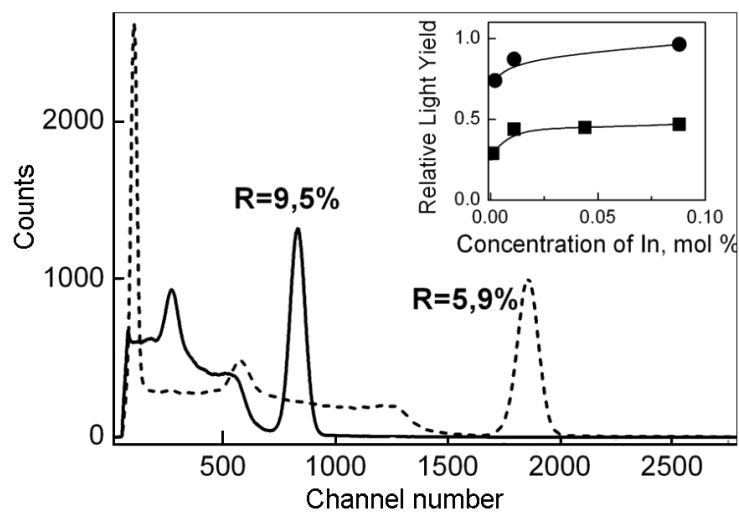

Fig. 6. Pulse height spectra of CsI:In (solid) and CsI:TI (dashed) crystals with the shaping time of $12 \mu \mathrm{s}$. Inset - concentration dependence of the pulse light yield at $\gamma$-excitation of $662 \mathrm{keV}{ }^{137} \mathrm{Cs}$ (squares) and radioluminescence at $\beta$-excitation of $546 \mathrm{keV}{ }^{90} \mathrm{Sr}^{-90} \mathrm{Y}$ (circles) in relation to CsI:TI.

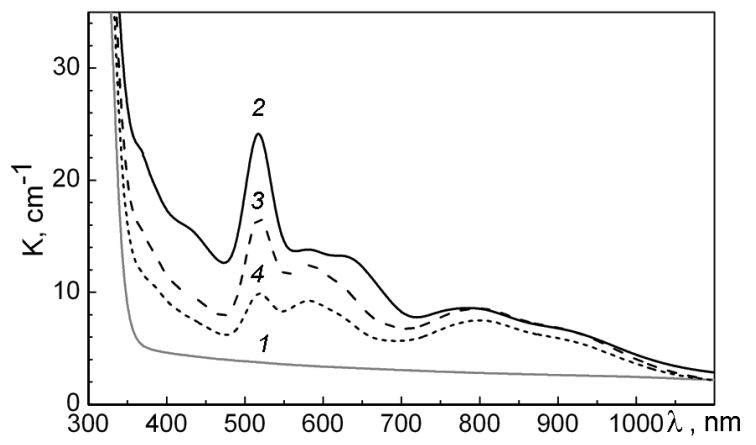

Fig. 7. Absorption spectra of Csl:0.05\% In crystal: initial - 1 , X-ray irradiated $\left(3 \cdot 10^{4} \mathrm{rad}\right)-2$, after 1 day $(3)$ and 3 days (4) storage at room temperature.

\subsection{Discussion}

It should be mentioned that the obtained data for scintillation efficiency of Csl:In crystals are comparable with that for Csl:TI scintillators. Relative simplicity of synthesis, emission band position (545 nm) convenient for registration and the light output, comparable with Csl:TI, indicate the potential feasibility of such crystals use in scintillation applications. Relatively slow decay $(1.9 \mu \mathrm{s})$ still allows the possibility to use such crystals for spectrometric measurements.

The data obtained deals with the study of laboratory samples. This is the first step in the full-scale study of this kind of scintillation material. This is why the data about functional and structural perfection of CsI:In should be considered as a lower esti- 
mate of potential of the new material. From this point of view the potential steps for implementation of industrial technologies of Csl:In scintillators growth should be analyzed.

Secondly, relatively fast saturation in the concentration dependence of the light output should be noted (Fig. 6). Within the framework of the laboratory samples growth using the Bridgeman method, we managed to obtain transparent and uniform Csl:In samples. However, the concentration of indium ions (regardless of the sufficiently high loads of $\mid \mathrm{nl}$ ) in the crystals remains low (up to $0.1 \mathrm{~mol}$. \%). Segregation coefficient of In in Csl was estimated to be about or less than $\sim 0.15$. Concentration of the activator in the upper and lower parts differs by the factor of 2-3. When exceeding the limiting solubility, a decomposition of the solid solution occurs, manifesting in micron size inclusions appearance in the crystal. We suppose that alternative growth methods and use of co-doping can allow attaining a higher dopant concentration.

Another possible way to improve the scintillation properties of CsI:In crystals is to reduce the amount of unwanted anionic impurities. Their presence in the crystals determines the detrimental contributions of slow scintillation component and afterglow (similarly to Csl:TI [13, 14]). Delayed luminescence kinetics under excitation at the fundamental absorption edge, as well as millisecond afterglow indicate the presence of deep carriers trapping levels in Csl:In crystals. In this assumption the difference between light yield of the crystals, measured by the current mode method, and the yield (determined by the position of the photo-peak of pulse height spectra) can be explained. In the latter case not all the light emitted by the crystal is integrated.

The factor of the crystal purity plays a significant role in the generation and accumulation of radiation defects. We shall note that the radiation resistance of Csl:In crystals decreases with the increase of the dopant concentration which is similar to Csl:TI. The tendency to the radiation coloration of Csl:In can be explained by a number of reasons. One of them is more significant difference in $\mathrm{In}^{+}$and $\mathrm{Cs}^{+}$ionic radii, providing a higher probability of creation and stabilization of structural defects (color centers) in the vicinity of the dopant ions. The second one is connected with the tendency of $\mathrm{In}^{+}$ions to charge carriers capture with formation of $\operatorname{In}^{0}$ and $\ln ^{2+}$ centers. Moreover, the increased radiation damage can be related to the presence of oxygen-containing admixture traces which is testified by the corresponding peaks in IR absorption spectra of the investigated crystals.

\section{Conclusions}

Csl:In single crystals with the dopant concentrations from $10^{-4}-$ to $10^{-1} \mathrm{~mol}$. \% were grown using the Bridgman method. Indium segregation coefficient in Csl lattice was estimated to be about 0.15 .

In Csl:In luminescence spectra under photo and X-ray excitation there is an intense band around $545 \mathrm{~nm}$ characterized by FWHM of $0.46 \mathrm{eV}$. Excitation and luminescence spectra do not overlap, which preconditions the absence of re-absorption. Thus the spectral composition and decay kinetics of luminescence are sufficiently close to the parameters of conventional Csl:TI scintillator.

The data on scintillation properties of the material are of the most importance and interest. It was shown that the absolute light output of Csl:In crystals, obtained from the pulse height spectra measurements with the shaping time of $12 \mu \mathrm{s}$ is 27000 photons $/ \mathrm{MeV}$. A significant part of the emitted light is concentrated in the longer decay components of the scintillation pulse and afterglow of the scintillator. Measurements of the integral light output in the current mode have shown that the total light yield of Csl:In attains that of Csl:TI (60 000 photons/MeV).

Overall, Indium can be an efficient activator for alkali halides, and considered as an alternative dopant for Csl, because of its sufficiently high light yield and absence of toxicity. Main disadvantages of Csl:In are high afterglow and low radiation stability.

Acknowledgements. The authors are indebted to D.Sofronov for IR transmittance measurements, and to I.Zenya for his help in radiative decay measurements. This work is supported by EC FP7 programme INCO.2010-6.1 NMP, grant agreement No.266531 (2010) "Strengthening Ukraine and EU research cooperation in the field of Material Sciences" (project acronym SUCCESS). 


\section{References}

1. Ren-Yuan Zhu, Proc. of SPIE, 7079, 70790W (2008).

2. http://www.amcrys-h.com/PiBeta.htm

3. V.Goriletsky, L.Eidelman et al., Nucl. Tracks Radiat. Meas., 21, 109 (1993).

4. C.W.E.van Eijk, Nucl. Instr. Meth. Phys. Res. A, 509, 17 (2003).

5. D.Simkin, T.Belliveau et al., J.Luminescence., 31, 320 (1984).

6. V.Sivasankar, K.Schmitt et al., J.Luminescence, 33, 409 (1985).

7. L.Grudskaya, Yu.Tsirlin et al., Zh.Prikl. Spect., 5, 655 (1966).
8. http://www.amcrys-h.com/Main_Frame.htm

9. M.Moszynski, M.Kapusta et al., IEEE Trans. Nuc.Sci., 44, 1052 (1997).

10. A.Ranfagni, D.Mugnai et al., Adv.Phys., 32, 823 (1983).

11. L.Trefilova, T.Charkina et al., J.Luminescence, 102-103, 543 (2003).

12. M.A.H.Chowdhury, S.Watts et al., Nucl.Instr. and Meth. Phys. Res. A, 432, 147 (1999).

13. C.Brecher, A.Lempicki et al., Nucl. Instr. and Meth. Phys. Res. A, 558, 450 (2006).

14. A.Kudin, A.Shkoropatenko et al., Functional Materials, 16, 275 (2009). 